\title{
Al Qur'an Recitation Method in Early Childhood in Integrated Islamic Kindergarten Playgroup
}

\author{
Sasmi Nelwati ${ }^{1, *}$, Adriantoni ${ }^{2}$, Gusma Nelly ${ }^{3}$ \\ ${ }^{1}$ Universitas Islam Negeri Imam Bonjol, Padang, Indonesia \\ ${ }^{2}$ Sekolah Tinggi Keguruan dan Ilmu Pendidikan Adzkia Padang, Padang, Indonesia \\ ${ }^{3}$ Sekolah Dasar Islam Terpadu Az-zahra Muko-muko, Muko-muko, Indonesia \\ *Email: sasminelwati@uinib.ac.id
}

\begin{abstract}
This thesis is motivated by the fact that children have the ability to memorize the Qur'an. When in memorizing the Qur'an the teachers uses an interesting method. The methods used include gefal method, talaqqi method, takriry method, and the fahim Qur'an method. In using this method can simplify and speed up children in memorizing Al-Qur'an. The sort of this research is descriptive. The Primary source of data is Tahfizh teachers, while secondary data sources are vice principals, students and children in kindergarten. Data collection techniques and tools are observation, interviews and documentation. The results of this study are as follows: 1) the gefal's methods, the teachers are collaborating the system of memorization with a definite signal movement. 2) the talaqqi's method which means the students listen to the verses which are going to be memorized from teacher's memorization and the students dictate the newly memorized verses to the teachers. 3) the method of Takriry al-Qiraati al-Juz'i which means memorizing with repitation and modification. 4) the method of FAHIM Qur'an which is the method of al-Qur'an through educative gaming. The evaluation applied is the evaluation conducted and evaluation monthly. The proponent factors of this are student's talents and interests, the deliberation of motivation, reward and gifts as well the cooperation between the teachers and parents
\end{abstract}

Keywords: gefal method, talaqqi, takriry al-Qiraati al-Juz'i, fahim Qur'an

\section{INTRODUCTION}

Education obtained by children for the first time comes from both parents. From the statement in the first paragraph explained, apart from parents the process of coaching and education received by the child also comes from the environment and his life experience. Therefore parents must always guide their children so as not to be affected by unfavorable environments, besides that parents also have to provide experiences that are guiding children to get to know their religion early on. Why do parents need to teach children to know their religion from an early age? Because early childhood is a golden period (golden age) for the development of children in the process of absorbing education.

Then explained by Samsul Munir that, Education for children is very urgent to be applied early on. Educating children from birth, in this case parents must pay attention to the basic points of the teachings of the sunnah of the Prophet. Educating in a humanist way will be more striking towards the success of children's education [1]. Introducing religion is also an important education that should be given by parents, through education to be able to distinguish between good and bad, accustom children to behave politely, speak well, teach children to read / introduce the Qur'an, be heard with the holy verses of the Qur'an since I was a baby or since I was in the womb.

In the book, Ulumul Qur'an Science for Understanding Revelation is written:

When someone hears the world $\mathrm{Al}$-Quran, he emmediately knows that what is meant is Kalam Allah or Kalamullah subhanahu wa ta'ala revealed to the Prophet Muhammad who read it worship, the composition of words and their contents are miracles, contained in the mushaf and quoted mut mutuk muthat.

During the time of the Prophet Muhammad the Arabs were mostly illiterate. They do not yet know paper as a stationery as it is now. Therefore every time the Prophet receives a revelation he always memorizes, then he is conveyed to his friends and instructed to memorize it and write it on stones, palm fronds, animal skins and anything that can be used to write it [3].

Among the greatest features of the Qur'an is to be the only holy book memorized by many people in this world. None of the holy books memorized parts of letters, sentences, letters and even their societies such as the Qur'an. He is remembered in the hearts and minds of his memorizers. This can be proven at the same time understandable, because the Qur'an is a book whose language is maintained 
and has been guaranteed by Allah SWT will always be guarded and maintained.

One form of realization is that Allah SWT prepares chosen people who will memorize the Qur'an and guard the purity of their sentences and readings. So, if there are enemies of Islam who try to change or replace just one sentence or one word, it will definitely be known, before all of that is widely circulated in the midst of Islamic society. So one way to preserve and maintain the authenticity and holiness of the Qur'an is to memorize it. Because memorization of the Qur'an itself has been done by the Prophet Muhammad, friends of the Prophet and by many Muslims in this world. Many of us meet people who memorized the Qur'an. They not only come from the intellectuals and the owners of high intelligence. Children under five, teenagers, adults, parents, and even those who are considered to have physical or mental deficiencies can memorize the Qur'an so that they get a special Muslim title in the sight of Allah [5]. People who have memorized the Qur'an appropriately will be the motivation of parents to educate their children to be able to memorize the Qur'an. Especially in this period many stories that tell or display early childhood who can memorize the Qur'an in print or electronic media.

Memorizing the Qur'an is worship, but in this day and age where modernization and globalization cannot be dammed it greatly influences the present and future generations. This has an psychological impact on adults and children. To attract interest in reading and memorizing the Qur'an, a planned and systematic method of memorizing the Qur'an is needed.

Preschool education aims to help lay the foundations towards the development of attitudes, knowledge, skills and creativity needed by students in adjusting to their environment and for further growth and development. At present due to the limitations of parents, both in terms of time and ability, the education of pre-school children is starting to be handed over to institutions that are believed to be either playgroups or kindergartens. One of the educational agents for children is kindergarten, where children get stimulation of all aspects of their development; physical, thinking, social, emotional and moral. Management (TK) is done by a head and assisted by other education personnel (PP No. 27/1990) [6].

In the development of Islamic education in Indonesia many religious-based schools have sprung up, one of which is TKIT Adzkia III Padang, explained that this educational institution aims to prepare the formation of a generation of Qur'ani, namely a generation that is committed to the Qur'an as a source of behavior, foothold life and referrals for all matters.

\section{METHOD}

\subsection{Types of research}

This research is a field research with a qualitative descriptive approach. Descriptive research is "A method of examining the status of a group of people, an object, a condition, a system of thought, or a class of events in the present. The purpose of this descriptive study is to make a systematic, factual and accurate description, picture or painting of the facts, properties and relationships between the phenomena investigated "[7]. Based on the explanation above, the author in conducting this research will use a qualitative descriptive method or the writer will provide and describe symptoms, facts and events clearly about the Al-Qur'an Memorization Method in Early Childhood in PG-TKIT Adzkia III Padang2.2 Non Formal Education Educators And Education Staffs Profile

\subsection{Data and Data Sources}

The data source is "objects, people, places to observe observing, reading, or asking about data" [8]. As for the sources of data in this study are: Primary data is "Data obtained directly from the community, whether done through interviews, observations and so on" [9]. As the primary data source in this study is, Tahfizh Al-Qur'an Teacher at PG Adzkia III Integrated Islamic Kindergarten III Padang. Secondary Data is "Data obtained from or derived from the literature of certain institutions, which supports the truth of the facts of the object under study (Ibid: 88), which is a secondary source of data in research, namely the deputy headmaster and homeroom teacher in PG-TK Islam Integrated Adzkia III Padang.

\subsection{Data Collection Techniques and Tools}

In getting accurate data to reveal the above problems, the researchers used the technique:

\subsubsection{Observasion}

Observations include observations of attention to objects using sensory devices [10]. In this study, researchers used a data collection tool in the form of guidelines for observation and participation in order to find out how the Al-Qur'an Memorization Method in Early Childhood in PG-TKIT Adzkia III Padang. The method used is to conduct direct observations in Adzkia Padang Kindergarten by seeing, hearing and other sensing. Direct observation has the intention to observe and see first hand the activities carried out. The author's observations are to observe the gefal method applied to early childhood, the talaqqi method applied to early childhood, the al-Qiraati al-Juz'i takriry method that is applied to early childhood, 
the fahim qur'an method applied to early childhood and supporting factors in the implementation of the Qur'an memorization method in early childhood in PG-TKIT Adzkia III Padang.

\subsubsection{Interview}

Interview is conducting direct communication with data sources, to obtain clearer information sources that have not been obtained through observation by asking a number of questions that are related to the problem in question. Interviews were conducted with the deputy headmaster, homeroom teacher and teacher Tahfizh TKIT Adzkia III Padang. This research researchers conducted by using open interviews, namely interviews that use a guideline of the subject matter studied [11]. Aspects to be interviewed are related to the Al-Qur'an Memorization Method in Early Childhood in PG-TKIT Adzkia III Padang.

\subsubsection{Dokumentation}

Documentation of how to collect data through written records, such as archives and including evidence about opinions, theories, propositions, or laws and others related to research problems [12]. Like seeing the archives or documentation in the field and learning report in the form of report cards.

\subsection{Data Processing and Analysis Techniques}

After the data is collected from observations, interviews, and documentation, then researchers will process the data using descriptive data analysis, meaning that the data obtained is not poured in the form of numbers but remains in a qualitative form. Testing data by means of existing data compared with a criterion that has been set in a theoretical basis [13]. In processing this qualitative data, the author uses the process of inductive thinking, meaning that the processing of data starts from the data collected through observation, interviews, and documentation, then general conclusions are drawn. The data analysis technique used is qualitative data analysis, which is carried out on data obtained through observation, interviews and documentation using qualitative descriptive analysis techniques, data analysis techniques used are:Reduksi data Reducing data means summarizing, choosing the main points, focusing on the important things, looking for themes and patterns and discarding unnecessary ones.

\subsubsection{Presentation of data}

Data presentation is done in the form of brief descriptions, charts, relationship, between categories, flow charts and the like. Usually the one that is often used is narrative text.

\subsubsection{Conclusion drawing and verification (conlusion drawing and verification)}

Researchers try to draw conclusions and verify by looking for the meaning of each symptom he gets from the field [14]

\section{RESULTS AND DISCUSSION}

Based on research results Al-Qur'an memorization method in early childhood in PG-TKIT Adzkia III Padang. namely as follows:

\subsection{Gefal Method applied to Early Childhood in PG-TKIT Adzkia III Padang.}

The purpose of using this GFAL method is to make it easier and faster for students to pursue the target of memorizing the Qur'an with hand and body gestures, students are also more in love with the Qur'an and can practice it in daily life, so as to give birth to generations of the Qur'an 'ani.

\subsection{Talaqqi method applied to Early Childhood in PG-TKIT Adzkia III Padang.}

The purpose of using the Talaqqi method is to facilitate the teacher in guiding students to memorize the Qur'an because teachers and students face to face can facilitate students in memorizing the Qur'an.

The talaqqi method is a method in which the teacher and students deal directly in the form of two ways in its implementation, the first is that students listen to the verses to be memorized from the teacher's reading. Second, students deposit the memorization that they just memorized to the teacher. Because this method requires more concentration of students, early childhood memorization is new, if playing around is certainly difficult to memorize the Qur'an. This method is also suitable for early childhood because the young child he listens to is happier than direct reading. 


\subsection{Al-Qiraati Al-Juz'i Takriry Method which is applied to Early Childhood in Adzkia III PG- TKIT Padang.}

The purpose of using the al-Qiraati al-juz'i takriry method is to make it easier for students to memorize the Qur'an, because this method is repeated and accompanied by modifications. So that when using this method students more quickly catch memorization and students can also exceed the memorization target that we have set.

Al-Qiraati al-Juz'i's method of Al-Qosimi version, this method is a method of memorization by means of repetition and modifications. Implementation of learning with First of all students with the superintendent's guide repeats the letter / verse that he has memorized. After that, read together 4 verses that will be memorized. Only then the superintendent reads the first verse to be memorized and imitated by his students up to 5 times. Then the students are told to repeat the first verse together 5 times. Besides that the cleric also justified recitation which is still not quite right or wrong. After memorizing everything, then each student is tested for memorization by mentioning the letter number as well. Then proceed with memorizing the fourth verse, the way it is like memorizing the first verse only, when repeating together students are told to repeat from the first verse and the fourth verse, by mentioning the verse number. After memorizing all students are tested one by one to repeat the first and fourth verses by mentioning the verse number. then proceed with memorization in verse two and verse three. After all memorizing tested one by one to repeat the first verse to the fourth verse by mentioning the verse number ".

\subsection{FAHIM Qur'an method applied to Early Childhood in PG-TKIT Adzkia III Padang.}

The purpose of using this method in memorization is so that the teacher is able to create a pleasant learning atmosphere and so students can easily memorize each of these verses. The method of memorizing is very important especially for young children so that they can easily memorize it and feel happy with what they memorize.

The method that can help students not eliminate learning while playing in memorizing verses of the Qur'an is the FAHIM Qur'an method, where the FAHIM Qur'an method is used when students feel bored, sleepy, by inviting students to play while reciting verses Al-Qur'an. Like a child while playing, jumping up and down in ceramic tiles by reciting the verse he memorized.

In tahfizh learning evaluation is important in an activity as a benchmark for the success of a job. Evaluation is an activity that is designed to find out whether students have or have not reached the target set. Then it can be seen that the evaluation (assessment) used for the method of memorizing the Qur'an at TKIT Adzkia III Padang is a daily evaluation and monthly evaluation.

\subsubsection{Daily rote evaluation}

This evaluation is very important for students, with this as an educator must know the extent to which the memorization of students while rote evaluation is done every hour before starting, students are asked 5 people a day to display or repeat the rote, what I see from memorization is fluency and the recitation. Then the daily evaluation of students is done before learning begins, by asking who is there to repeat the rote at home. Here students are asked who is there repeating memorization then they are pointed and invited to repeat the memorization in front, and may also sit if students do not want to stand up, whose names are children of course they are looking for where the fun, if forced children will not want to read the letter had memorized it. the purpose of this evaluation is so that memorization that has been memorized by students is not lost from their memories.

\subsubsection{Monthly evaluation}

This monthly evaluation is done once a month. Evaluation is done to find out the whole memorization of students. Does the memorization that they memorized so far have forgotten or not, but it also can increase the enthusiasm of students in memorization and can continuously add to memorization. The rote evaluation is done once a month by external examiners or not from the Adzkia TKIT but we find it from the adzkia foundation to test the students' rote learning. In conducting this monthly evaluation we provide special time outside of class hours. The purpose of this evaluation is so that students are more diligent in memorizing.

\subsection{Supporting Factors in Memorizing the Qur'an in early childhood at TKIT Adzkia III Padang.}

\subsubsection{Internal Factor}

\subsubsection{Talent}

The students here are very talented, with their talents they look seriously when learning to memorize the Qur'an and the seriousness shows, every time a memorization verse that is repeated students can already imitate it, because they are at home also guided by their parents, then we repeat again there are even new verses that can connect the verse that was read

\subsubsection{Interest}

TKIT is interested in memorizing the Qur'an, but when memorizing the Qur'an, there are still those who do not 
read or pay attention. Even then, because the verse read is a new verse that will be memorized. so they cannot listen to the memorized verse.

\subsubsection{External Factor}

For young children, we really need to provide motivation so that they are not lazy in memorizing the Qur'an. Examples of motivation that $\mathrm{I}$ give are sholeh and sholehah children who want to enter heaven with the cleric, if you want to go to heaven, pious and pious children of pious let us memorize the diligent, and listen and listen to his friend again recite the verse he reads.

The forms of motivation given to students in improving memorization of the Qur'an are as follows:

\subsubsection{Provide motivation in the form of praise and rewards}

In my ongoing leaning prosecc, I always provide motivation in the form of praise to children who memorize the Qur'an, such as (great cleric children have memorized fluently). By giving these compliments so that students are more enthusiastic and active in learning and memorizing the Qur'an. Giving motivation is also not only by giving praise but by giving a reward, if only by giving praise it is not certain that they will be motivated in memorizing the Koran but I give a challenge to students that those who memorize the Koran more, will be given a gift, but I do not forget to give input about the gift given that all this is nothing compared to the reply from Allah.

\subsubsection{Collaboration with parents}

As educators, they really need cooperation with students' parents because the process of memorizing the Qur'an will not take place optimally without any collaboration with parents. To achieve the goal of memorizing students at school we teach how to memorize the Qur'an and at home parents repeat what students learn at school.

Learning success of each student is not enough if there is only harmony between the students and students, students and teachers and teachers and teachers. But more important than that, there is a good relationship between the school and parents (guardians of students). For this reason, the school has a special program, the Qur'an tahfiz program. Which is carried out every day which is directly guided by the homeroom teacher each and 3 times a week guided directly by a special tahfizh teacher, then repeated with parents at home.

\section{CONCLUSION}

Based on the results of research that the author put forward in Chapter IV on "the method of memorizing the Qur'an in early childhood in PG-TKIT Adzkia III Padang. Then the conclusions can be drawn as follows: Al-Qur'an memorization method in early childhood at TKIT Adzkia III Padang used is the Gefal method, the Talaqqi method, the Takriry al-Qiraati al-Juz'i method and the FAHIM Qur'an method. Evaluations used in memorizing the Qur'an are daily and monthly evaluations. Supporting factors are the children's talents and interests, providing motivation, rewards or charter and the collaboration of the teacher with the child's parents.

\section{REFERENCES}

[1] S. M. Amin, Menyiapkan Masa Depan Anak Secara Islami. Jakarta: Amzah, 2007.

[2] A. Hermawan, Ulumul Qur'an Ilmu Untuk Memahami Wahyu. Bandung: PT. Remaja Rosdakarya, 2011.

[3] M. Zen, Tata Cara/Problematika Menghafal AlQur'an dan Petunjuk-petunjuknya. Jakarta: Pustaka AlHusna, 1985.

[4] D. A. RI, Al-Qur'an dan Terjemahnya. Bandung: Syaamil Qur'an, 2007.

[5] S. A. Sayyid, Balita Pun Menghafal Al-Qur'an. Solo: Tinta Media, 2012.

[6] A. E. Abdullah, Pendekatan Psikologi Pendidikan Anak. Yogyakarta: Pustaka Timur, 2006.

[7] M. Nazir, Metode Penelitian. Bogor: Ghalia Indonesia, 2005.

[8] S. Arikunto, Manajemen Penelitian. Jakarta: Rineka Cipta, 2006.

[9] P. J. Subagyo, Metodologi Penelitian dalam Teori dan Praktek. Jakarta: PT. Rineka Cipta, 2006.

[10] S. Arikunto, Prosedur Penelitian Suatu Pendekatan Praktik. Jakarta: Rineka Cipta, 2013.

[11] C. Narbuko, Metodologi Penelitian. Jakarta: Bumi Aksara, 2005.

[12] Margono, Metode Penelitian Pendidikan. Jakarta: Rineka Cipta, 2007.

[13] H. Sutrisno, Metodologi Penelitian Pendidikan. Bandung: Pustaka Setia, 1998.

[14] P. Sugiyono, Metode Penelitian Pendidikan. Bandung: Alfabeta, 2014. 